\title{
Review
}

\section{Cytolytic P2X purinoceptors}

\author{
Francesco Di Virgilio ${ }^{1,2,4}$, Paola Chiozzi ${ }^{1}$, Simonetta Falzoni ${ }^{1}$, \\ Davide Ferrari ${ }^{1}$, Juana M. Sanz ${ }^{1}$, Vishwanath Venketaraman ${ }^{1}$ \\ and Olavio R. Baricordi ${ }^{2,3}$ \\ ${ }^{1}$ Department of Experimental and Diagnostic Medicine, Section of General \\ Pathology, University of Ferrara, Italy \\ 2 Center of Biotechnology, University of Ferrara, Italy \\ ${ }^{3}$ Department of Experimental and Diagnostic Medicine, Section of Medical \\ Genetics, University of Ferrara, Italy \\ ${ }^{4}$ corresponding author: Dr. Francesco Di Virgilio, Department of Experimental \\ and Diagnostic Medicine, Section of General Pathology, Via Borsari, 46, \\ I-44100 Ferrara, Italy Tel: 532 -291353; fax: 523-247278; \\ e-mail: fdv@ifeuniv.unife.it
}

Received 8.9.97; accepted 22.10.97

Edited by M. Piacentini

\begin{abstract}
Anedoctal evidence accumulated over almost 20 years has shown that many different cell types are killed by sustained exposure to high concentrations of extracellular ATP. The plasma membrane receptors involved have been pharmacologically characterized and cloned during the last 3 years, and named purinergic P2X. P2X receptors share an intriguing structural relatedness with Caenorhabditis elegans degenerins and mammalian amiloridesensitive $\mathrm{Na}$ channels (ENaCs). Depending on the ATP dose, length of stimulation and receptor subtype, P2X receptor stimulation may cause necrosis or apoptosis. The intracellular pathways activated are poorly known, but the perturbation in intracellular ion homeostasis clearly plays a major role. ICE proteases (caspases) are also triggered, nonetheless their activation is not requested for ATP-dependent cell death. The physiological meaning of $\mathrm{P} 2 \mathrm{X}$ receptor-dependent cytotoxicity is not understood, but an involvement in immune-mediated reactions is postulated.
\end{abstract}

Keywords: ATP; purinergic receptors; cell death; cytotocity; inflammation; apoptosis

Abbreviations: $\mathrm{ENaC}$, amiloride-sensitive $\mathrm{NA}^{+}$channel; ICE, Interleukin 1- $\beta$. converting enzyme; Kir, inward rectifier $\mathrm{K}^{+}$channel; mscL, Escherichia coli mechanosensitive channel; CNS, central nervous system; LAK, lymphokineactivated killer cells; LPS, bacterial lipopolysaccharide; APC, antigen-presenting cell; SEB, staphylococcal enterotoxin B.

\section{P2X receptors: what are they?}

$\mathrm{P} 2 \mathrm{X}$ receptors are plasma membrane ligand-gated ion channels activated by ATP (Abbracchio and Burnstock, 1994; Buell et al, 1996a). They belong to the growing family of receptors for extracellular nucleotides whose other members are the P2Y receptors (Fredholm et al, 1994; Brake and Julius, 1996). For this reason, P2X and P2Y receptors are collectively named $\mathrm{P} 2$ purinergic receptors, while plasma membrane receptors that bind adenosine are referred to as purinergic P1 (Burnstock and Kennedy, 1985). According to current classification of plasma membrane receptors for neurotransmitters, $\mathrm{P} 2 \mathrm{X}$ and $\mathrm{P} 2 \mathrm{Y}$ receptors are also often referred to as ionotropic and metabotropic, respectively (Abbracchio and Burnstock, 1994). Early evidence for the presence of ATP-ligated receptors goes back to observation by Holton and coworkers on vasomotor responses evoked by antidromic stimulation of the rabbit ear (Holton and Perry, 1951; Holton and Holton, 1954) and of Burnstock and colleagues on the contracturant effect of ATP applied to vascular smooth muscle (Burnstock et al, 1972). Now it is generally accepted that extracellular nucleotides play a major role in cell to cell communication (Brake and Julius, 1996). It was initially thought that P2X receptor/ channels were only expressed by excitable cells, but it is clear that they are also present in many other cells of widely different origin (Buell et al, 1996a). Recently, their identification in mononuclear phagocytes and lymphocytes has attracted great interest in view of a possible involvement in immune modulation (Di Virgilio et al, 1996a,b).

\section{Molecular structure of $\mathrm{P} 2 \mathrm{X}$ receptors}

The first cloning of P2X receptors was reported in 1994 by two different groups. Valera et al (1994) isolated a cDNA encoding an ATP-gated channel from smooth muscle of rat vas deferens, while Brake et al (1994) isolated a cDNA of another ATP-gated channel from the rat pheochromocytoma cell line PC12. The smooth muscle clone was named P2X while the PC12 clone was named P2X 2 . Following these initial reports, several clones for other P2X receptors have been isolated from rat and human cells, amounting now to a total number of seven (Buell et al, 1996a). Determination of the aminoacid sequence has unveiled a surprising structural similarity of P2X channels with other families of ion channels such as degenerins of Caenorhabditis elegans (Deg-1, Mec- 4 and $\mathrm{Mec}-10)$, the epithelial sodium channels of mammalian cells (ENaCs), the inward-rectifier potassium channel (Kir), and the mechanosensitive channel of $E$. coli ( $\mathrm{mscL}$ ) (Corey and Garcia-Anoveros, 1996; North, 1996) (Figure 1). All these families of ion channels share the same structural motif: two putative membrane spanning domains with both the $\mathrm{N}$ and $\mathrm{C}$ 
termini on the cytoplasmic side and a bulky extracellular domain (Figure 2). Kir is an exception, as this channel has a smaller extracellular domain that forms a loop that goes back half way across the plasma membrane.

Size of P2X channels ranges from 379 aminoacids for $\mathrm{P}^{2} \mathrm{X}_{6}$ (Collo et al, 1996; Soto et al, 1996b) to 595 for P2X the largest member of the family (Suprenant et al, 1996; Rassendren et al, 1997). Overall, P2X channels share little sequence identity. The sharing of sequence identity is higher in the $\mathrm{N}$-terminus and in the putative extracellular domain, and very low in the $\mathrm{C}$ terminus. Furthermore, ten cysteine residues are conserved in the extracellular region, suggesting that establishment of S-S bonds may cause a highly convoluted tertiary structure. The only known agonist for these channels is ATP, but quite intriguingly their putative extracellular domain shows no obvious ATPbinding sequences. It has been suggested that, in analogy to a previous proposal for the catalytic site of ATPases, parallel $\beta$ sheet structures that are likely to be present in the ectodomain of $\mathrm{P} 2 \mathrm{X}$ receptors may generate a binding site for ATP, but this is still to be proven (Buell et al, 1996a). No other soluble physiological activator of P2X

(a)

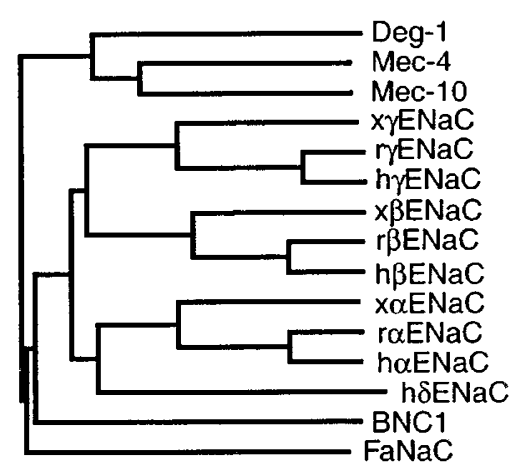

(b)

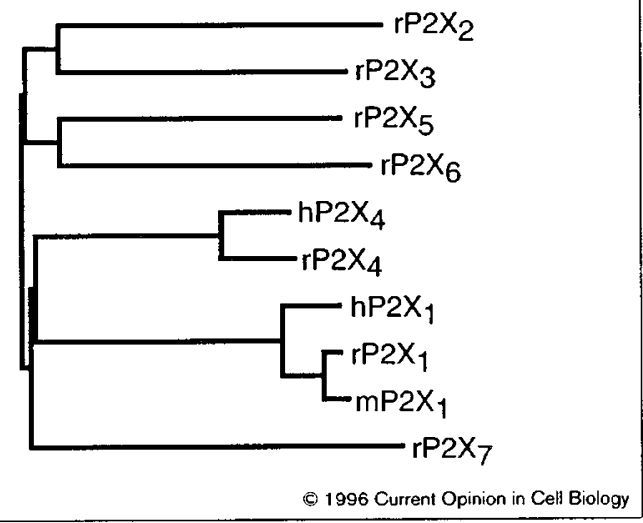

Figure 1 Dendrograms showing the structural relatedness within the two proposed subfamilies of plasma membrane channel subunits with two hydrophobic domains. (a) Relatedness within the subfamily of $C$. elegans degenerins (Deg-1, Mec-4 and Mec-10), mammalian epithelial Na channels (ENaC), human brain Na channel (BNC1) and Helix aspersa FMRFamidegated channel $(\mathrm{FaNaC})$. (b) Relatedness within the family of P2X channels h, human; r, rat; m, mouse; $x$, Xenopus (reproduced from North, 1996, with permission) channels has been so far discovered, nor is it known whether the bulky ecto-domain can interact with structural components of the extracellular matrix, as shown for unc105 of C. elegans (Liu et al, 1996), thus endowing P2X channels with the ability to respond to mechanostimulation. It may be of interest that $\mathrm{Zn}^{2+}$, a cation that is abundant in the central nervous system (CNS), highly potentiates current responses of some P2X channels by shifting the ATP dose-dependency to lower concentrations ( $\mathrm{Li}$ et al, 1993). This is reminiscent of the effect of $\mathrm{Zn}^{2+}$ on NMDA receptor activity (Hollman et al, 1993), although in this case increase in potency is due to enhancement of maximal response without altering the agonist dose-response curve. Potentiation by $\mathrm{Zn}^{2+}$ could be due to allosteric modulation or to interaction with ATP, but this is not currently known.

As pointed out above, the $\mathrm{COOH}$ tail is the less conserved domain among the seven members of $\mathrm{P} 2 \mathrm{X}$ subfamily. It is not known if this may determine the functional behaviour of the different $\mathrm{P} 2 \mathrm{X}$ receptors/channels, with one relevant exception, $\mathrm{P}_{2} \mathrm{X}_{7}$. The $\mathrm{C}$-terminal in this receptor is much longer than in other P2X channels (for example, 28 aminoacids for $\mathrm{P}_{2} \mathrm{X}_{4}$, and 118 for $\mathrm{P}_{2} \mathrm{X}_{2}$ versus 240 for $\mathrm{P}_{2} \mathrm{X}_{7}$ ). Truncation of $\mathrm{P} 2 \mathrm{X}_{7}$ C-terminal at position 418 drastically modifies the permeability properties, changing this receptor from a non-selective pore into a cation selective channel (see below) (Suprenant et al, 1996). However, while the C-terminal tail of $\mathrm{P}_{2} \mathrm{X}_{7}$ appears to be necessary for the pore-forming activity of $\mathrm{P}_{2} \mathrm{X}_{7}$, it does not seem to be sufficient by itself to confer the pore-forming activity, as chimeric $\mathrm{P} 2 \mathrm{X}_{2}$ receptors in which the native $\mathrm{C}$-tail was replaced with the $\mathrm{P} 2 \mathrm{X}_{7} \mathrm{C}$-tail, do not form pores (Anne marie Surprenant, personal communication).

While there are few doubts that the functional channel must consist of multiple P2X subunits, it is not known whether the native channel is formed by homo or hetero polymerization, nor do we have hints as to subunit stoichiometry. Only for $\mathrm{P}_{2} \mathrm{X}_{2}$ and $\mathrm{P}_{2} \mathrm{X}_{3}$ found in sensory neurons has it been shown that the native receptor is very likely formed by heteromultimerization of the two different subunits (Chen et al, 1995; Lewis et al, 1995), maybe in a pentameric structure.

\section{Functional properties of $\mathrm{P} 2 \mathrm{X}$ receptors}

P2X receptors form cation selective channels. In patch clamp experiments, ATP $\mathrm{EC}_{50}$ for activation of cloned rat $\mathrm{P} 2 \mathrm{X}$ receptors ranges from $0.7 \mu \mathrm{M}\left(\mathrm{P}_{2} \mathrm{X}_{3}\right)$ to $115 \mu \mathrm{M}\left(\mathrm{P} 2 \mathrm{X}_{7}\right)$. At least 10-fold higher ATP concentration is needed to activate the cloned human $P 2 X_{7}$ receptor. High agonist concentrations have also been reported for activation of native $\mathrm{P} 2 \mathrm{X}$ receptors in macrophages, fibroblasts and mast cells (see Steinberg and Silverstein, 1987; Buisman et al, 1988; Tatham and Lindau, 1990; Pizzo et al, 1992). Although permeability properties are not fully defined, there is substantial agreement that $\mathrm{Na}^{+}$and $\mathrm{K}^{+}$are equipermeant while $\mathrm{Cs}^{+}$is less permeant (Valera et al, 1994; Brake et al, 1994; Soto et al, 1996a). In general, $\mathrm{Ca}^{2+}$ is also very permeant $\left(\mathrm{P}_{\mathrm{Ca}} / \mathrm{P}_{\mathrm{Na}} \approx 4\right)$ (Buell et al, 1996a), but there is some controversy on this issue in the previous literature, probably due to cell type differences (Benham and Tsien, 1987; Friel and Bean, 1988; 


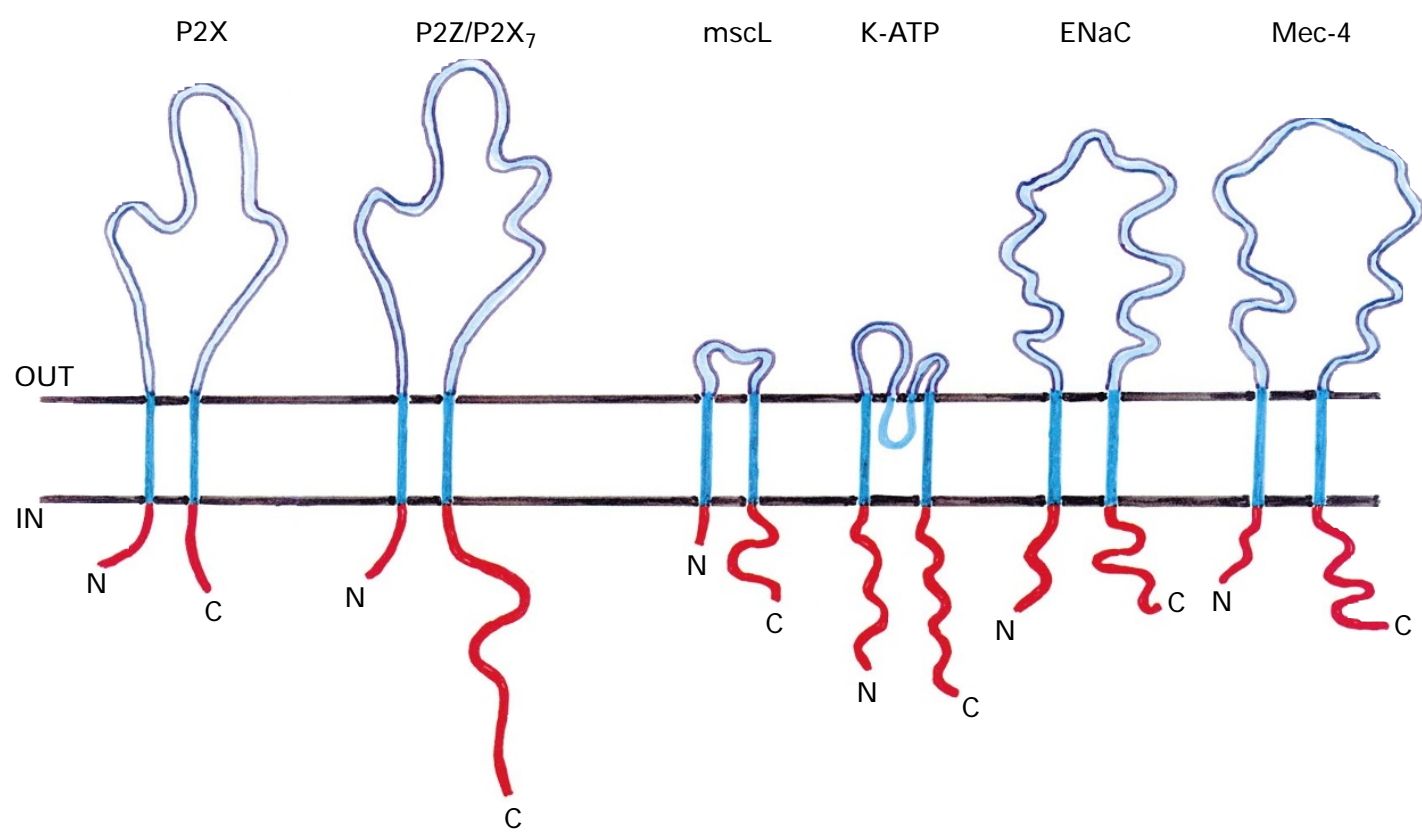

Figure 2 Schematic drawing of different types of channels with two hydrophobic domains. This drawing shows the general architecture of ATP-gated channel subunits (P2X), the peculiar P2Z/P2X 7 subunit (note the extended COOH tail), the mechanosensitive channel of E. coli (mscL), the ATP/ADP-gated inward rectifier $\mathrm{K}^{+}$channel (K-ATP), the mammalian epithelial amiloride-sensitive $\mathrm{Na}$ channel (ENaC), the C. elegans mechanosensitive channel (Mec-4). Light blue, ectodomain; green, membrane-spanning regions; red, cytoplasmic domains

Bean et al, 1990). P2X 7 has a completely different and unique behaviour. While brief applications of ATP evoke inward currents carried by cations, sustained stimulation (or repetitive applications) induce the appearance of a large non-selective pore (Surprenant et al, 1996; Rassendren et al, 1997). This pore allows transmembrane fluxes of choline, methylglucamine, propidium iodide, YO-PRO and lucifer yellow. This behaviour closely mimicks that of the native ATP-gated channel, preliminary named $\mathrm{P} 2 \mathrm{Z}$, described in fibroblasts (Rozengurt et al, 1977; Makan and Heppel, 1978; Pizzo et al, 1992), mast cells (Cockcroft and Gomperts, 1979), macrophages (Steinberg and Silverstein, 1987; Steinberg et al, 1987; Di Virgilio et al, 1988) and other cells (Kitagawa and Akamatsu, 1986). Activation of this receptor by ATP induces uptake of extracellular tracer molecules such as lucifer yellow and even the $\mathrm{Ca}^{2+}$ chelator fura-2 in its acidic form. The pharmacology of $P 2 X_{7}$ and the native $P 2 Z$ receptor is very similar: both appear to be activated by $\mathrm{ATP}^{4-}$, rather than by $\mathrm{Ca} / \mathrm{Mg}-\mathrm{ATP}$, and for both receptors benzoylbenzoylATP is about tenfold more active than ATP (Steinberg and Silverstein, 1987; Murgia et al, 1992a; Suprenant et al, 1996; Rassendren et al, 1997). In our laboratory we have selected several cell clones from $\mathrm{J} 774$ macrophages and N13 or N9 microglial cells that functionally either lack or hyperexpress the $\mathrm{P} 2 \mathrm{Z}$ receptor (Murgia et al, 1992a; Chiozzi et al, 1996; Ferrari et al, 1996). P2Z-less and P2Z-high clones are also negative or strongly positive, respectively, to in situ hybridization with a specific $\mathrm{P}_{2} \mathrm{X}_{7}$ probe or to a polyclonal antibody directed against the $\mathrm{COOH}$ tail of $\mathrm{P}_{2} \mathrm{X}_{7}$ (Chiozzi et al, 1997; Ferrari et al, 1997a). This is strong evidence in favour of $\mathrm{P} 2 \mathrm{Z}$ being formed by the assembly of $\mathrm{P} 2 \mathrm{X}_{7}$ subunits, although it is not clear whether other $\mathrm{P} 2 \mathrm{X}$ subunits $\left(\mathrm{P}_{2} \mathrm{X}_{1}\right.$ ?) may also participate to the channel phenotypically known as P2Z. Macrophages and microglial cells may express other ATPgated receptors in addition to $\mathrm{P} 2 \mathrm{Z} / \mathrm{P} 2 \mathrm{X}_{7}$. This is evident from the observation that macrophage and microglial cell clones negative for $\mathrm{P} 2 \mathrm{Z} / \mathrm{P} 2 \mathrm{X}_{7}$ receptor expression are transiently depolarized by ATP, as if they expressed an inactivating ATP

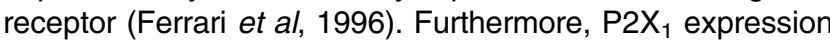
has been detected in HL60 and THP-1 cells at various levels of differentiation (Buell et al, 1996c; Dubyak et al, 1996).

The most striking property of P2Z/P2X is the ability to mediate a reversible permeabilization of the plasma membrane, provided the ATP pulse is of short duration (10-15 min) (Rozengurt et al, 1977; Gomperts and Fernandez, 1985; Steinberg and Silverstein, 1987; Di Virgilio and Steinberg, 1993). More sustained stimulations cause an irreversible cell damage that eventually leads to cell death (Kitagawa et al, 1988; Nagelkerke et al, 1989; Blanchard et al, 1991; Murgia et al, 1992b; Falzoni et al, 1995; Modderman et al, 1994; Vijweide et al, 1995; Zoeteweij et al, 1996).

\section{P2X receptors and cell death}

ATP-gated plasma membrane channels were firstly described in fibroblasts and mast cells about 20 years ago. Yet for a long time they were considered little more than a curiosity and no effort was made towards the understanding of their role in cell physiology. In the second half of the $80 \mathrm{~s}$, a few laboratories undertook a systematic investigation of these receptor/ channels and showed that sustained stimulation of certain 
cells and cell lines (melanoma and mouse fibroblast cells, $\mathrm{J} 774$ mouse macrophages, primary mouse and human lymphocytes, mouse lymphoma and mastocytoma cells) with extracellular ATP caused cell death (Steinberg and Silverstein, 1987; Kitagawa et al, 1988; Di Virgilio et al, 1989; Wiley and Dubyak, 1989; Zanovello et al, 1990). Our group also showed that cell death could be due to either colloido-osmotic lysis or apoptosis depending on the cell type and length of stimulation (Zanovello et al, 1990; Murgia et al, 1992a). These early demonstrations were extensively confirmed by several other laboratories both in primary cell cultures and in cell lines (Filippini et al, 1990a; Zheng et al, 1991; Blanchard et al, 1991, 1995; Spranzi et al, 1993; Zoetewij et al, 1996; Macino et al, 1996; Correale et al, 1997), and eventually validated in HEK293 cells stably transfected with the recombinant P2X receptor (Suprenant et al, 1996; Ferrari et al, 1997a). Early studies also showed that some cell types, such as cytotoxic T lymphocytes (CTLs) and lymphokine-activated killer (LAK) cells were inherently refractory to ATP stimulation (Di Virgilio et al, 1989; Zanovello et al, 1990; Filippini et al, 1990a). Although protection could be afforded in theory by a high expression of plasma membrane ecto-ATPases, there are now few doubts that the main reason resides in the lack of expression of $\mathrm{P} 2 \mathrm{X}$ receptors in these cells. Along this line, we showed that CTLs and LAK cells remained resistant even in the virtual absence of extracellular divalent cations (Di Virgilio et al, 1989), a condition that prevents enzymatic activity of ATPases. In addition, CTLs do not express an ectoATPase activity significantly greater than that measured in ATPsensitive cells. All these observations suggested that susceptibility to ATP-mediated cytotoxicity was conferred by expression of a plasma membrane ATP-gated channel, and refractorines depended on the absence of such channel. Following studies demonstrated that ATP was cytotoxic not only to cells that express the typical 'permeabilizing' $P 2 Z$ receptor, such as macrophages, but also to those cells in which this nucleotide activates a cation-selective channel, with no evidence of permeabilization to larger hydrophylic solutes (Pizzo et al, 1991; Ferrari et al, 1994). This lead us to suggest that plasma membrane ATP-gated channels may form a new family of ion channels with different permeability and ion selectivity, but linked by the common property of causing cell death under conditions of sustained stimulation (Murgia et al, 1992b). Recent data have confirmed that immune cells susceptible to ATP-mediated cytotoxicity express either $\mathrm{P}_{2} \mathrm{X}_{1}$ or $\mathrm{P}_{2} \mathrm{X}_{7}$ or maybe both (Buell et al, 1996c; Chvatchko et al, 1996; Dubyak et al, 1996). There has been some discussion in the past about the possibility that some cytolytic effect could be mediated via P2Y receptors. However, this can be now safely excluded because ATPresistant macrophages and microglial cell clones do express $\mathrm{P} 2 \mathrm{Y}$ receptors to a level indistinguishable from that found in sensitive cells.

It was not completely unexpected that prolonged activation of P2X channels could cause necrotic lysis as several bacterial toxins (Fussle et al, 1981) or immune soluble factors (i.e. complement or perforins) (Young et al, 1986; Henkart, 1985) are known to lyse cells by causing formation of plasma membrane pores. Furthermore, as pointed out by Pizzo et al (1991), ATP receptors share intriguing functional similarities with receptors for excitatory aminoacids in central neurons. These latter receptors also gate channels that cause $\mathrm{Ca}^{2+}$ influx in the absence of $\mathrm{Ca}^{2+}$ mobilization from stores, trigger depolarization of plasma membrane and are involved in cell death (excitotoxicity). On the contrary, it was somewhat unexpected that $\mathrm{P} 2 \mathrm{X}$ receptor activation could also cause apoptosis.

The first indication that $\mathrm{P} 2 \mathrm{X}$ receptors could be involved in apoptosis came from experiments performed in mouse P815 cells. In these cells, ATP was shown to cause a clear DNA fragmentation, indistinguishable from that found as a consequence of co-incubation with lymphokine-activated killer (LAK) cells (Zanovello et al, 1990), well known cytotoxic effectors that kill target cells by apoptosis. DNA fragmentation was specifically triggered by ATP, very rapid and associated with the induction of transmembrane ion fluxes. The apoptotic effect of ATP was soon confirmed by Zheng et al (1991) in mouse thymocytes. These authors performed a thorough morphological investigation showing that ATP not only caused DNA fragmentation, but also membrane blebbing, cell shrinkage, nuclear condensation and apoptotic bodies formation. Interest in the possible involvement of $\mathrm{P} 2 \mathrm{X}$ receptors in apoptosis was rekindled by the first reports of the aminoacid sequence and tentative membrane topology of $\mathrm{P} 2 \mathrm{X}$ receptors from rat smooth muscle (Valera et al, 1994) and rat pheochromocytoma (PC12) (Brake et al, 1994) cells. It was immediately apparent that $\mathrm{P}_{2} \mathrm{X}_{1}$ was nothing but the product of the RP-2 gene, which had previously been shown to be expressed during the early phases of apoptosis in rat thymocytes (Owen et al, 1991). Further support for a role of $\mathrm{P}_{2 \mathrm{X}_{1}}$ has recently come from the demonstration that mouse thymocytes exhibit an increase of $\mathrm{P}_{2} \mathrm{X}_{1}$ mRNA content after in vitro dexamethasone treatment and in vivo challenge with the superantigen staphylococcal enterotoxin B (SEB) (Chvatchko et al, 1996 but see also Jiang et al, 1996, for an opposite view).

The ATP degradation product adenosine has also been shown to cause apoptosis in several cell types via activation of a purinergic $P 1$ receptor of the $A_{1}$ or $A_{3}$ subtype (see Abbracchio, 1996, for a recent review).

Human monocyte-derived macrophages can undergo ATP-dependent apoptosis, especially if stimulated in a pulsed rather than continuous fashion (Molloy et al, 1994). In the case of a sustained stimulation, the most likely outcome is cell death by necrosis. Other factors may also affect the final outcome (i.e. necrosis versus apoptosis) as primary human and mouse macrophages appear to be more easily induced to apoptosis by ATP, while some tumor cell lines, such as the $\mathbf{J 7 7 4}$ mouse macrophages, in our experience are more prone to undergo necrosis (Murgia et al, 1992a). Susceptibility of macrophages to ATP. dependent death may have significant practical applications as Molloy et al (1994) have shown that stimulation with ATP of macrophages infected with the intracellular organism bacillus Calmette Guerin (BCG), not only caused apoptosis of the macrophages but also killed the intracellular organism. On the contrary, macrophage killing with other cytotoxic agents, e.g. hydrogen peroxide, 
released viable microrganisms. This observation has been recently confirmed with BCG and also extended to a virulent strain of Mycobacterium tuberculosis (V. Vishwanath, S. Falzoni, P. Chiozzi and F. Di Virgilio, unpublished observations; G. Mancino, G. Barbolini, F. Di Virgilio and V. Colizzi, manuscript in preparation).

\section{Mechanism of P2X receptor-mediated cytotoxicity}

Cell death appears to be due to the prolonged opening of P2X channels in the presence of the agonist, resulting in the activation of a non desensitizing channel. Although most of $\mathrm{P} 2 \mathrm{X}$ receptors (i.e. $\mathrm{P} 2 \mathrm{X}_{2}$ and $\mathrm{P} 2 \mathrm{X}_{4-7}$, but quite intriguingly not $P 2 X_{1}$ ) fulfil this criterion, any extrapolation from cloned to native receptors is dangerous, as in many cases electrophysiological behaviour of transfected $\mathrm{P} 2 \mathrm{X}$ receptors is affected by the recipient cell (e.g. P2X4 expressed in HEK293 cells versus oocytes) (Buell et al, 1996c; Seguela et al, 1996; Soto et al, 1996a). Early cellular events following $\mathrm{P} 2 \mathrm{X}$ receptor activation include $\mathrm{Ca}^{2+}$ and $\mathrm{Na}^{+}$influx, $\mathrm{K}^{+}$efflux, plasma membrane depolarization, swelling and disaggregation of the cytoskeletal network. In macrophages, extensive formation of phase lucent vesicles is also observed. How these changes contribute to cell death is not well understood, however it is clear that the inbalance in ion homeostasis plays a crucial role. In the presence of physiological concentration of monovalent cations, $\mathrm{Ca}^{2+}$ is not needed for ATP-dependent cytotoxicity. Replacement of extracellular $\mathrm{Na}^{+}$and $\mathrm{K}^{+}$with isoosmolar $\mathrm{Ca}^{2+}$-free sucrose greatly delays cell death, that however is rapidly triggered by re-addition of $\mathrm{Ca}^{2+}$ (Pizzo et al, 1991; Murgia et al, 1992a). Thus it seems that while $\mathrm{Ca}^{2+}$ is not needed for ATP-mediated cytotoxicity in standard $\mathrm{Na}^{+}$and $\mathrm{K}^{+}$-containing buffers, it is however capable of restoring the ATP cytotoxic effect when added to a sucrose medium that by itself does not sustain cytotoxicity. Whether $\mathrm{Ca}^{2+}$-dependent and independent ATP-mediated cytotoxicity involves different intracellular pathways has not been investigated.

Participation of other intracellular second messengers has not been explored, but for a recent report showing that tyrosin kinases and phosphatases may be involved (Bronte et al, 1996).

In macrophages and microglial cells, ATP triggers production of mature interleukin- $\beta$ via activation of interleukin-1 $\beta$-converting enzyme (ICE) (Perregaux and Gabel, 1994; Perregaux et al, 1996; Ferrari et al, 1996, 1997b), a member of the growing family of cystein proteases (caspases) that mediate apoptosis (Alnemri et al, 1996; Nagata, 1997). Experiments performed in our laboratory with the specific cell permeant substrate YVAD have further confirmed that extracellular ATP triggers ICE activation (J. Sanz and F. Di Virgilio, manuscript in preparation). However, it seems also clear that this pathway is not needed for ATP-dependent cytotoxicity, as YVAD-inhibited macrophages are still susceptible to ATPdependent apoptosis (Nett-Fiordalisi et al, 1995). In addition, also macrophages from knock-out mice for ICE, which are unable to produce $\mathrm{IL}-1 \beta$ in response to ATP, undergo ATP-dependent apoptosis (Li et al, 1995). This is in agreement with other reports showing that ICE activation is not an obligatory step in the apoptotic pathway (Nagata, 1997).

The issue of whether stimulation of the $\mathrm{P} 2 \mathrm{X}_{7} / \mathrm{P} 2 \mathrm{Z}$ receptor is always associated to cell death, is controversial. In general, the outcome is very dependent on the target cell type, presumably reflecting the density of $\mathrm{P}_{2} \mathrm{X}_{7} /$ $\mathrm{P} 2 \mathrm{Z}$ receptor expression. There are also species differences, as the human $\mathrm{P}_{2} \mathrm{X}_{7}$ has a lower affinity than the rat counterpart (Rassendren et al, 1997), and likewise higher nucleotide concentrations are required to induce permeabilization of human than mouse macrophages (Hickman et al, 1994; Falzoni et al, 1995). This may explain why ATP is a good apoptotic stimulus for human but not $\mathrm{J} 774$ mouse macrophages, as these latter cells, being more sensitive, are more prone to undergo fast ATP-mediated necrosis rather than apoptosis. In the mouse macrophage cell line $\mathrm{J} 774$, a short (less than $15 \mathrm{~min}$ ) activation of the $\mathrm{P} 2 \mathrm{X}_{7} / \mathrm{P} 2 \mathrm{Z}$ receptor causes a fully reversible permeabilization. These cells, after the short ATP pulse, resume their pre-pulse morphology, spread on the substrate again and start to divide. The ability to fully recover physiological functions after permeabilization has been the basis for the selection and establishment of $\mathrm{J} 774$ cell clones that express a high

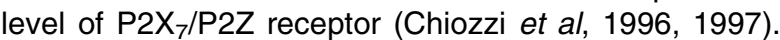

\section{P2X receptors and cytotoxicity: a laboratory curiosity or a physiologically relevant phenomenon?}

The physiological meaning of ATP-mediated cytotoxicity is an open question. There are few doubts that ATP is released via non lytic pathways by many cells. Central (White et al, 1978) and peripheral (von Kugelgen and Starke, 1991; Todorov et al, 1997) neurons and platelets (Meyers et al, 1982; Colman et al, 1990) release ATP by exocytotic secretion; epithelial and endothelial cells also release ATP (Pearson and Gordon, 1979; Reisin et al, 1994), maybe via plasma membrane transporters belonging to the family of ABC (ATP-binding cassette) proteins (Abraham et al, 1993, 1996; Reisin et al, 1994; Schwiebert et al, 1995); T lymphocytes (Filippini et al, 1990b) and macrophages (Ferrari et al, 1997c) also secrete ATP in the pericellular space via a yet to be identified mechanism. Furthermore, being the average cytoplasmic ATP concentration in the range of $5-10 \mathrm{mM}$, any agent that causes acute plasma membrane damage is also expected to release ATP. Thus, it is likely that under physiological and pathological conditions significant ATP concentrations can accumulate in the extracellular space, may be at sites of close cell-to-cell contact, where in a protected compartment ATP will not easily dilute into the interstitial fluid. Obviously, the extracellular ATP concentration is affected not only by ATP release but also by ATP hydrolysis by ubiquitous ectoATPases (Zimmermann, 1996). Recent experiments by Robson and co-workers (1997) show that during an inflammatory reaction the ATP diphosphohydrolase activity is downregulated, thus providing an additional factor that contributes to the accumulation of extracellular ATP.

Our and Sitkovsky's group originally proposed that extracellular ATP could participate in cytotoxic reactions in the immune system (Di Virgilio et al, 1989, 1990; Filippini 
et al, 1990a). Admittedly, there was no direct proof supporting this hypothesis, but rather a number of circumstantial observations such as the $\mathrm{Ca}^{2+}$ independency of ATP-mediated cytotoxicity, the apoptotic mechanism, the strong synergism with TNF (Bronte et al, 1993), the remarkable refractoriness to ATP of cytotoxic $T$ cells and of Lymphokine Activated Killer (LAK) cells (Di Virgilio et al, 1990; Filippini et al., 1990a). This hypothesis was probably too naive as originally postulated. Nonetheless, convergent reports from many different laboratories point to an important role for ATP and purinergic P2X receptors in cytotoxic events during the immune and inflammatory reactions.

Blanchard et al (1995) have recently proposed that ATP receptors could be involved in the elimination of antigenpresenting cells by $\mathrm{CD}^{+}$and $\mathrm{CD}^{+} \mathrm{T}$ lymphocytes. This observation is potentially of great interest as killing of antigen-presenting cells (APCs) is known to participate in the down regulation of the immune response. Expression of the $\mathrm{P} 2 \mathrm{Z} / \mathrm{P} 2 \mathrm{X}_{7}$ receptor is up-regulated by IFN- $\gamma$ (Blanchard et al, 1991; Falzoni et al, 1995; Humphreys and Dubyak, 1996), a cytokine that is also well known for increasing expression of MHC-II molecules and therefore antigenpresenting activity of APCs (Farrar and Schreiber, 1993). Thus, it seems that IFN- $\gamma$-stimulated macrophages on one hand increase their ability to stimulate the immune response, and on the other express a safe-guard device (the P2Z/P2X 7 receptor) that act as a feed-back, inhibitory mechanism. The powerful inflammatory stimulus bacterial lipopolysaccharide (LPS) can also upregulate $\mathrm{P} 2 \mathrm{Z} / \mathrm{P} 2 \mathrm{X}_{7}$ receptor expression in THP-1 macrophages (Humphreys and Dubyak, 1996).

Likely occurrence of significant accumulation of extracellular ATP at sites of immune and inflammatory reactions, upregulation of the prototypical cytotoxic receptor (P2Z/ $\mathrm{P} 2 \mathrm{X}_{7}$ ) by inflammatory cytokines and bacterial products and increased susceptibility to ATP of macrophages as compared to blood monocytes, suggest that $\mathrm{P} 2 \mathrm{X}$ purinergic receptors play an important role in the defense mechanisms of the body (Di Virgilio, 1995). In certain conditions (i.e. in the presence of extensive tissue damage, strong stimulation of active ATP release or powerful inhibition of plasma membrane ecto-ATPases (see Robson et al, 1997), or maybe under the cooperative effect of all these factors together), sufficient ATP may accumulate in the pericellular space to trigger $\mathrm{P} 2 \mathrm{Z} / \mathrm{P} 2 \mathrm{X}_{7}$ receptor activation and thus cell death. P2Z/P2X $\mathrm{X}_{7}$-mediated cell death should not be necessarily accidental, but in some cases might be the result of a coordinated activation of immune cells, aimed for example at the killing of antigen presenting cells (APCs) during the physiological process of antigen presentation, or at the elimination of phagocytes parasitized by pathogens that survive phagocytosis ('Samson shall die with all the Philistines!') (Di Virgilio, 1995).

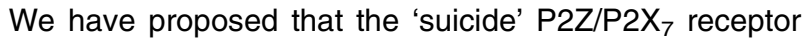
could also have a role in spontaneous cell death, such as that occurring in cell cultures. Chiozzi et al (1996) have shown that $\mathrm{J} 774$ macrophages in vitro undergo a basal rate of cell death that is significantly increased upon reaching confluence. The extent of cell death is much higher in those
J774 macrophage clones that hyper express the P2Z/P2X receptor and virtually nil in the clones that were selected for lack of $\mathrm{P} 2 \mathrm{Z} / \mathrm{P} 2 \mathrm{X}_{7}$. In addition, incubation in the presence of ATP-consuming enzymes, such as apyrase or hexokinase, or pretreatment with oxidized ATP, an inhibitor of the P2Z/ $\mathrm{P}_{2} \mathrm{X}_{7}$ receptor, greatly reduced cell death. Our interpretation of these experiments is that macrophages in vitro are continuously exposed to an autocrine/paracrine stimulation by ATP, that causes a basal activation of the P2Z/P2X receptor which in turn might trigger a cytotoxic response when a given threshold is reached.

Cytotoxicity may be just one of many functions. At low levels of stimulation (i.e. low extracellular ATP concentration), P2X receptors primarily co-operate in cell activation (e.g. cytokine release or lysosomal content release), or even participate in cell fusion events (see Falzoni et al, 1995 and Chiozzi et al, 1997).

$\mathrm{P} 2 \mathrm{X}_{1}$, the other P2X receptor for which a role in cell death has been proposed, could be involved in thymic selection. In experiments reported by Chvatchko et al (1996), P2X 1 receptor expression was upregulated in thymocytes by apoptotic stimuli such as dexamethasone and SEB, a superantigen that ligates the $T$ cell receptor. Furthermore, exogenous ATP caused apoptosis that was prevented by apyrase, an enzyme that degrades ATP. Since these effects were restricted to thymocytes (peripheral $\mathrm{T}$ lymphocytes appear not to express $\mathrm{P} 2 \mathrm{X}_{1}$ ), the authors propose that this ATP-gated channel could be involved in clonal deletion in the thymus.

\section{Conclusions and future perspectives}

Cloning and sequencing and functional characterization of ATP-gated ion channels (P2X receptors) has disclosed an intriguing new family of plasma membrane channels that share structural homology with other ion channels (degenerins) known to be involved in cell death in $C$. elegans. Amiloride-sensitive $\mathrm{Na}$ channels related to degenerins (MDEGs for mammalian degenerins) have been recently cloned from human brain. It appears that two membranespanning channels may form a new superfamily of molecules endowed with the ability to mediate, at least in vitro, a death signal. Several questions await an answer: is there any evidence that cytotoxic activity is also present in vivo? Is extracellular ATP the physiological ligand, or have we so far missed the actual activatory counterreceptor (e.g. a matrix or soluble protein)? What is the mechanism of subunit assembly? Do these receptors interact with other intracellular proteins?

We think that clarification of these, and many other unsolved questions, will not only deepen our knowledge of cell physiology and metabolism but will also provide us with new therapeutic agents.

\section{Acknowledgements}

J.M.S. was supported by a fellowship awarded by the Spanish Ministry for Education and Scientific Research and V.V. by a grant awarded by UNESCO-CNR (United Nations Educational and Cultural OrganizationNational Research Council). This work was supported by the Italian 
Ministry for Scientific Research (40\% and 60\%), the National Research Council of Italy, the Italian Association for Cancer Research (AIRC), the IX AIDS Project, the II Tuberculosis Project, and Telethon of Italy.

\section{References}

Abbracchio MP (1996) P1 and P2 receptors in cell growth and differentiation. Drug Dev. Res. 39: 393-406

Abbracchio MP and Burnstock G (1994) Purinoceptors: are there families of P2X and P2Y receptors? Pharmacol. Ther. 64: 445-475

Abraham EH, Pratt AG, Gerweck L, Seneveratne T, Arceci RJ, Kramer R, Guidotti G and Cantiello HF (1993) The multidrug resistance ( $m d r 1)$ gene product functions as an ATP channel. Proc. Natl. Acad. Sci. USA 90: 312-316

Abraham EH, Vos P, Kahn J, Grubman SA, Jefferson DM, Ding I and Okunieff P (1996) Cystic fibrosis hetero and homozygosity associated with inhibition of breast cancer growth. Nat. Med. 2: 593-596

Alnmeri ES, Livingston DJ, Nicholson DW, Salvesen G, Thornberry NA, Wong WW and Yuan J (1996) Human ICE/CED-3 protease nomenclature. Cell, 87: 171

Bean BP, Williams CA and Ceelen PW (1990) ATP-activated channels in rat and bullfrog sensory neurons: current-voltage relation and single channel behavior. J. Neurosci. 10: 11-19

Benham CD and Tsien RW (1987) A novel receptor-operated $\mathrm{Ca}^{2+}$-permeable channel activated by ATP in smooth muscle. Nature, 328: 275-278

Blanchard DK, McMillen S and Djeu JY (1991) IFN- $\gamma$ enhances sensitivity of human macrophages to extracellular ATP-mediated lysis. J. Immunol. 147:2759-2585

Blanchard DK, Wei S, Duan C, Pericle F, Diaz JI and Djeu JY (1995) Role of extracellular adenosine triphosphate in the cytotoxic T lymphocyte-mediated lysis of antigen presenting cells. Blood 85: 3173-3182

Brake AJ and Julius D (1996) Signalling by extracellular nucleotides. Annu. Rev. Cell Dev. Biol. 12: $519-541$

Brake AJ, Wagenbach MJ and Julius D (1994) New structural motif for ligand-gated ion channels defined by an ionotropic ATP receptor. Nature 371: 519-523

Bronte V, Macino B, Zambon A, Rosato A, Mandruzzato S, Zanovello P and Collavo D (1996) Protein tyrosine kinases and phosphatases control apoptosis induced by extracellular adenosine 5'-triphosphate. Biochem. Biophys. Res. Commun. 218 $344-351$

Bronte V, Zanovello P, Rosato A, Zambon A, Mandruzzato S, Pizzo P, Di Virgilio F and Collavo D (1993) Synergistic effect of extracellular adenosine 5 'triphosphate and tumor necrosis factor on DNA degradation. Cell. Immunol. 152: 110-119

Buell G, Collo G and Rassendren F (1996a) P2X receptors: an emerging channel family. Eur. J. Neurosci. 8: 2221-2228

Buell GN, Lewis C, Collo G, North RA and Suprenant A (1996b) An antagonist insensitive $P 2 X$ receptor expressed in epithelia and brain. EMBO J. 15: 55-62

Buell G, Michel AD, Lewis C, Collo G, Humphrey PPA and Surprenant A(1996c) P2X activation in HL60 cells. Blood 87: 2659-2664

Buisman HP, Steinberg TH, Fischbarg J, Silverstein SC, Vogelzang SA, Ince C, Ypey DL and Leijh PCJ (1988) Extracellular ATP induces a large non-selective conductance in macrophage plasma membrane. Proc. Natl. Acad. Sci. USA, 85 7988- 7992

Burnstock G, Dumsday B and Smythe A (1972) Atropine resistant excitation of the urinary bladder: the possibility of transmission via nerves releasing a purine nucleotide. Br. J. Pharmacol. 44: 451-461

Burnstock $G$ and Kennedy C (1985) Is there a basis for distinguishing two types of P2purinoceptor? Gen. Pharmacol. 16: 433-440

Chen C-C, Akopian AN, Sivilotti L, Colquhoun D, Burnstock G and Wood JN (1995) A P2X purinoceptor expressed by a subset of sensory neurons. Nature 377: 428431

Chiozzi P, Murgia M, Falzoni S, Ferrari D and Di Virgilio F (1996) Role of the purinergic $\mathrm{P} 2 \mathrm{Z}$ receptor in spontaneous cell death in $\mathrm{J} 774$ macrophage cultures. Biochem. Biophys. Res. Commun. 218: 176-181

Chiozzi P, Sanz JM, Ferrari D, Falzoni S, Aleotti A, Buell GN, Collo G and Di Virigilio F (1997) Spontaneous cell fusion in macrophage cultures expressing high levels of the P2Z/P2X 7 receptor. J. Cell Biol. 138: 697-706

Chvatchko Y, Valera S, Aubry JP, Renno T, Buell G and Bonnefoy JY (1996) The involvement of an ATP-gated ion channel, $\mathrm{P}_{2} \mathrm{X}_{1}$, in thymocyte apoptosis. Immunity, 5: 275-283

Cockcroft S and Gomperts BD (1979) ATP induces nucleotide permeability in rat mast cells. Nature 279: $541-542$
Collo G, North RA, Kawashima E, Merlo-Pich E, Neidhart S, Surprenant A and Buell G (1996) Cloning of $P 2 X_{5}$ and $P 2 X_{6}$ receptors, and the distribution and properties of an extended family of ATP-gated ion channels. J. Neurosci. 16: 2495-2507

Colman R (1990) Aggregin: a platelet ADP receptor that mediates activation. FASEB J. 4: $1425-1435$

Corey DP and Garcia-Anoveros J (1996) Mechanosensation and the DEG/ENaC ion channels. Science 273: 323-324

Correale P, Tagliaferri P, Guarrasi R, Caraglia M, Giuliano M, Marinetti MR, Bianco AR and Procopio A (1997) Extracellular adenosine 5 '-triphosphate involvement in the death of LAK-engaged human tumor cells via P2X-receptor activation. Immunol. Lett. 55: 69-78

Di Virgilio F (1995) The P2Z purinoceptor: an intriguing role in immunity, inflammation and cell death. Immunol. Today 16: $524-528$

Di Virgilio F, Bronte V, Collavo D and Zanovello P (1989) Responses of mouse lymphocytes to extracellular adenosine 5 '-triphosphate (ATP). Lymphocytes with cytotoxic activity are resistant to the permeabilizing effects of ATP. J. Immunol. 143: 1955-1960

Di Virgilio F, Ferrari D, Chiozzi P, Falzoni S, Sanz J, Dal Susino M, Mutini C, Hanau S and Baricordi OR (1996a) Purinoceptor function in the immune system. Drug Dev. Res. 39: 319-329

Di Virgilio F, Ferrari D, Falzoni S, Chiozzi P, Munerati M, Steinberg TH and Baricordi OR (1996b) P2 purinoceptors in the immune system. Ciba F. Symp. 198: $290-$ 305

Di Virgilio F, MeyerBC, Greenberg S and Silverstein SC (1988) Fc receptor-mediated phagocytosis occurs in macrophages at exceedingly low cytosolic $\mathrm{Ca}^{2+}$ levels. J. Cell Biol. 106: 657-666

Di Virgilio F, Pizzo P, Zanovello P, Bronte V and Collavo D (1990) Extracellular ATP as a possible mediator of cell-mediated cytotoxicity. Immunol Today 149: 33723378

Di Virgilio F and Steinberg TH (1993) ATP permeabilization. In Cell and Tissue Culture: Laboratory Procedures (A Doyle, JB Griffiths and DG Newell eds) 5B: 4.1-4.8. Wiley \& Sons (Chichester)

Dubyak GR, Clifford EE, Humphreys BD, Kertsey SB and Martin KA (1996) Expression of multiple ATP receptor subtypes during the differentiation and inflammatory activation of myeloid leukocytes. Drug Dev. Res. 39: 269-278

Falzoni S, Munerati M, Ferrari D, Spisani S, Moretti S and Di Virgilio F (1995) The purinergic P2Z receptor of human macrophage cells. Characterization and possible physiological role. J. Clin. Invest. 95: 1207-1216

Farrar MA and Schreiber RD (1993) The molecular cell biology of interferone- $\gamma$ and its receptor. Annu. Rev. Immunol. 11: 571-611

Ferrari D, Chiozzi P, Falzoni S, Dal Susino M, Collo G, Buell GN and Di Virgilio F (1997a) ATP-mediated cytotoxicity in microglial cells. Neuropharmacology, 36 : $1295-1301$

FerrariD, Chiozzi P, Falzoni S, Dal Susino M, Melchiorri L, BaricordiORand Di Virgilio $F$ (1997b) Extracellular ATP triggers IL-1 $\beta$ release by activating the purinergic P2Z receptor of human macrophages. J. Immunol. 159: 1451-1458

Ferrari D, Chiozzi P, Falzoni S, Hanau S and Di Virgilio F (1997c) Purinergic modulation of Interleukin- $1 \beta$ release from microglial cells stimulated with bacterial endotoxin. J. Exp. Med. 185: 579-582

Ferrari D, Munerati M, Melchiorri L, Hanau S, Di Virgilio F and Baricordi OR (1994) Responses to extracellular ATP of lymphoblastoid cell lines from Duchenne muscular dystrophy patients. Am. J. Physiol. 267: C886-C892

Ferrari D, Villalba M, Chiozzi P, Falzoni S, Ricciardi-Castagnoli P and Di Virgilio F (1996) Mouse microglial cells express a plasma membrane pore gated by extracellular ATP. J. Immunol. 156: 1531 - 1539

Filippini A, Taffs RE, Agui T and Sitkovsky MV (1990a) ExtoATPase activity in cytolytic T lymphocytes: protection from the cytolytic effects of extracellular ATP. J. Biol. Chem. 265: 334-340

Filippini A, Taffs RE and Sitkovsky MV (1990b) Extracellular ATP in T-lymphocyte activation: possible role in effector function. Proc. Natl. Acad. Sci. USA 87: $8267-8271$

Fredholm BB, Abbracchio MP, Burnstock G, Daly JW, Harden TK, Jacobson KA, Leff $P$ and Williams M (1994) Nomenclature and classification of purinoceptors. Pharmacol. Rev. 46: 143-156

FrielDD and Bean DP (1988) Two ATP-activated conductances in bullfrog atrial cells. J. Gen. Physiol. 91: 1-27

Fussle R, Bhakdi S, Sziegoleit A, Tranum-Jensen J, Kranz T and Wellensiek H-J (1981) On the mechanisms of membrane-damage by S. aureus alpha-toxin. J. Cell Biol. 91: 83-90 
Gomperts BD and Fernandez JM (1985) Techniques for membrane permeabilization. Trends Biochem. Sci. 10: 414-417

Henkart PA (1985) Mechanisms of lymphocyte-mediated cytotoxicity. Annu. Rev. Immunol. 3: 31-58

Hickman SE, El Khoury J, Greenberg S, Schieren I and Silverstein SC (1994) P2Z adenosine triphosphate receptor activity in cultured human monocyte-derived macrophages. Blood 84: 2452-2456

Hollman M, Boulter J, Maron C, Beasley L, Sullivan J, Pecht G and Heinemann S (1993) Zin potentiates agonist-induced currents at certain splice variants of the NMDA receptor. Neuron 10: 943-954

Holton FA and Holton P (1954) The capillary dilator substance in dry powders of spinal roots: a possible role of adenosine triphosphate in chemical transmission from nerve endings. J. Physiol. 126: 124-140

Holton P and Perry WLM (1951) On the transmitter responsible for antidromic vasodilation in rabbits ear. J. Physiol. 114: 240-251

Humphreys BD and Dubyak GR (1996) Induction of the P2Z/P2X 7 nucleotide receptor and associated phospholipase $D$ activity by lipopolisaccharide and IFN$\gamma$ in the human THP-1 monocytic cell line. J. Immunol. 157: 5627-5637

Jiang S, Kull B, Fredholm BB and Orrenius S (1996) P2X purinoceptor is not important in thymocyte apoptosis. Immunol. Lett. 49: 197-201

Kitagawa T, Amano F and Akamatsu Y (1988) External ATP-induced passive permeability change and cell lysis of cultured transformed cells: action in serumcontaining growth media. Biochim. Biophys. Acta 941: 257-263

Kitagawa T and Akamatsu Y (1986) Control of membrane permeability by external ATP in mammalian cells: isolation of an ATP resistant variant from Chinese hamster ovary cells. Biochim. Biophys. Acta 860: 185-193

Lewis C, Neidhart S, Holy C, North RA, Buell G and Surprenant A (1995) Coexpression of $\mathrm{P}_{2} \mathrm{X}_{2}$ and $\mathrm{P} 2 \mathrm{X}_{3}$ receptor subunits can account for ATP-gated currents in sensory neurons. Nature 377: 432-435

Li P, Allen H, Banerjee S, Franklin S, Herzog L, Johnston C, McDowell J, Paskind M, Rodman L, Salfeld J, Towne E, Tracey D, Kamen R and Seshadri T (1995) Mice deficient in IL- $1 \beta$-converting enzyme are defective in production of mature IL-1 $\beta$ and resistant to endotoxic shock. Cell 80: 401-441

Li C, Peoples RW, Li Z and Weight FF (1993) $\mathrm{Zn}^{2+}$ potentiates excitatory action of ATP on mammalian neurons. Proc. Natl. Acad. Sci. USA 90: 8264-8267

Liu J, Schrank B and Waterson RH (1996) Interaction between a putative mechanosensory membrane channel and a collagen. Science 273: 361-364

Macino B, Zambon A, Milan G, Cabrelle A, Ruzzene M, Rosato A, Mandruzzato S, Quintieri L, Zanovello P and Collavo D (1996) CD45 regulates apoptosis induced by extracellular adenosine triphosphate and cytotoxic T lymphocytes. Biochem. Biophys. Res. Commun. 226: 769-776.

Makan NR and Heppel LA (1978) Control of glycolysis and the pentose phosphate shunt in transformed 3T3 cultures rendered permeable by ATP. J. Cell Physiol. 96: 87-94.

Meyers KM, Holmsen Hand Seachord CL (1982) Comparative study of platelet dense granules constituents. Am. J. Physiol. 243: R454-R461

Modderman WE, Vrijheid-Lammers T, Lowik CWGM and Nijweide PJ (1994) Removal of hematopoietic cells and macrophages from mouse bone marrow cultures: isolation of fibroblast like stromal cells. Exp. Hematol. 22: 194-201

Molloy A, Laochumroovorapong P and Kaplan G (1994) Apoptosis, but not necrosis, of infected monocytes is coupled with killing of intracellular bacillus CalmetteGuerin. J. Exp. Med. 180: 1499-1509

Murgia M, Pizzo P, Steinberg TH and Di Virgilio F (1992a) Characterization of the cytotoxic effect of extracellular ATP in J774 macrophages. Biochem. J. 288: 897-901

Murgia M, Pizzo P, Zanovello P, Zambon A and Di Virgilio F (1992b) In vitro cytotoxic effects of extracellular ATP. ATLA 20: 66-70

Nagata S (1997) Apoptosis by death factor. Cell 88: 355-365

Nagelkerke JF, Dogterom P, De Bont HJGM and Mulder GJ (1989) Prolonged high intracellular free calcium concentration induced by ATP are not immediately cytotoxic in isolated rat hepatocytes. Biochem. J. 263: 347-353

Nett-Fiordalisi M, Tomaselli K, Russel JH and Chaplin DD (1995) Macrophage apoptosis in the absence of active interleukin- $1 \beta$-converting enzyme. J. Leukoc. Biol. 58: 717-724

Nijweide PJ, Modderman WE and Hagenaars CE (1995) Extracellular adenosine triphosphate. A shock to hematopoietic cells. Clin. Orthop. 313: 92-102

North RA (1996) Families of ion channels with two hydrophobic segments. Curr. Op. Cell Biol. 8: $474-483$
Owen GP, Hahn WE and Cohen JJ (1991) Identification of mRNA associated with programmed cell death in immature thymocytes. Mol. Cell Biol. 11: 4177-4188

Pearson JD and Gordon JL (1979) Vascular endothelium and smooth muscle cells in culture selectively release adenine nucleotides. Nature 281: $384-386$

Perregaux D and Gabel CA (1994) Interleukin-1 $\beta$ maturation and release in response to ATP and nigericin. J. Biol. Chem. 269: 15195-15203

Perregaux DG, Laliberte RE and Gabel CA (1996) Human monocyte Interleukin-1 $\beta$ posttranslational processing. Evidence of a volume-regulated response. J. Biol. Chem. 271: 29830-29838

Pizzo P, Murgia M, Zambon A, Zanovello P, Bronte V, Pietrobon D and Di Virgilio F (1992) Role of P2Z purinergic receptors in ATP-mediated killing of tumor necrosis factor (TNF)-sensitive and TNF-resistant L929 fibroblasts. J. Immunol. 149: $3372-3378$

Pizzo P, Zanovello P, Bronte V and Di Virgilio F (1991) Extracellular ATP causes lysis of mouse lymphocytes and activates a plasma membrane ion channel. Biochem. J. 274: $139-144$

Rassendren F, Buell G, Virginio C, Collo G, North RA and Suprenant A (1997) The permeabilizing ATP receptor, P2X 7 . J. Biol. Chem. 272: 5482-5486

Reisin IL, Prat AG, Abraham EH, Amara JF, Gregory RJ, Ausiello DA and Cantiello HF (1994) The cystic fibrosis transmembrane conductance regulator is a dual ATP and chloride channel. J. Biol. Chem. 32: 20584-20591

Robson CR, Kaczmarek E, Siegel JB, Candinas D, Koziak K, Millan M, Hancock WW and Bach FH (1997) Loss of ATP diphosphohydrolase activity with endothelial cell activation. J. Exp. Med. 185: 153-163

Rozengurt E, Heppel LA and Friedberg I (1977) Effect of exogenous ATP on the permeability properties of transformed cultures of mouse cell lines. J. Biol. Chem. 252: $4584-4590$

SchwiebertEM, Egan ME, Hwang T-H, Fulmer SB, Allen SS, Cutting GR and Guggino WB (1995) CFTR regulates outwardly rectifying chloride channels through an autocrine mechanism involving ATP. Cell 81: 1063-1073

Sequela P, Haghighi A, Soghomian J and CooperE (1996)A novel neuronal P2XATP receptor ion channel with widespread distribution in the brain. J. Neurosci. 16: $448-455$

Soto F, Garcia-Guzman M, Gomez-Hernandez JM, Hollmann M, Karschin C and Stuhmer W (1996a) P2X $\alpha 4$ : and ATP-activated ionotropic receptor cloned from rat brain. Proc. Natl. Acad. Sci. USA 93: 3684-3688

Soto F, Garcia-Guzman M, Karschin C and Stuhmer W (1996b) Cloning and tissue distribution of a novel P2X receptor from rat brain. Biochem. Biophys. Res. Commun. 223: $456-460$

Spranzi E, Djeu JY, Hoffman SL, Epling-Burnette PK and Blanchard DK (1993) Lysis of human monocytic leukemia cells by extracellular adenosine triphosphate receptor. Blood 82: 1578-1585

Steinberg TH, Newman AS, Swanson JA and Silverstein SC (1987) ATP ${ }^{4-}$ permeabilizes the plasma membrane of mouse macrophages to fluorescent dyes. J. Biol. Chem. 262: $8884-8888$

Steinberg TH and Silverstein SC (1987) Extracellular ATP ${ }^{4}$ promotes cation fluxes in the J774 mouse macrophage cell line. J. Biol. Chem. 262: 3118-3122

Surprenant A, Rassendren F, Kawashima E, North RA and Buell G (1996) The cytolytic $\mathrm{P} 2 \mathrm{Z}$ receptor for extracellular ATP identified as a $\mathrm{P} 2 \mathrm{X}$ receptor $\left(\mathrm{P} 2 \mathrm{X}_{7}\right)$. Science 272: $735-7338$

Tatham PER and Lindau M (1990) ATP-induced pore formation in the plasma membrane of rat peritoneal mast cells. J. Gen. Physiol. 95: 459-476

Todorov LD, Mihaylova-Todorova S, Westfall TD, Sneddon P, Kennedy C, Bjur RA and Westfall DP (1997) Neuronal release of soluble nucleotidases and their role in neurotransmitter inactivation. Nature 387: 76-79

Valera S, Hussy N, Evans RJ, Adami N, North RA, Surprenant A and Buell G (1994) A new class of ligand-gated ion channel defined by $P 2 X$ receptor for extracellular ATP. Nature 371: $516-519$

von Kugelgen I and Starke K (1991) Release of noradrenaline and ATP by electrical stimulation and nicotine in guinea-pig vas deferens. Naunyn-Schmiedeberg's Arch. Pharmacol. 344: 419-429

Young JD, Cohn ZA and Podack ER (1986) The ninth component of complement and the pore-forming protein (perforin 1) from cytotoxic T cells: structural, immunological and functional similarities. Science 233: 184-190

White TD (1978) Release of ATP from a synaptosomal preparation by elevated extracellular $\mathrm{K}^{+}$and by veratridine. J. Neurochem. 30: 329-336 
Wiley JS and Dubyak GR (1989) Extracellular adenosine triphosphate increases cation permeability of chronic lymphocytic leukemia lymphocytes. Blood 73: $1316-1323$

Zanovello P, Bronte V, Rosato A, Pizzo P and Di Virgilio F (1990) Responses of mouse lymphocytes to extracellular ATP. II. Extracellular ATP causes cell typedependent lysis and DNA fragmentation. J. Immunol. 145: 1545-1550

Zheng LM, Zychlinsky A, Liu C-C, Ojcius DM and Young JDE (1991) Extracellular ATP as a trigger for apoptosis or programmed cell death. J. Cell Biol. 112: 279288
Zimmermann H (1996) Extracellular purine metabolism. Drug. Dev. Res. 39: 337 352

Zoetewij JP, van de Water B, de Bont HJ and Nagelkerke JF (1996) The role of a purinergic $\mathrm{P} 2 \mathrm{Z}$ receptor in calcium-dependent cell killing of isolated rat hepatocytes by extracellular adenosine triphosphate. Hepatology 23: 858-865 